Acta Universitatis Nicolai Copernici • Pedagogika XXXIII/2017

Nauki Humanistyczno-Społeczne • Zeszyt 438

DOI: http://dx.doi.org/10.12775/AUNC_PED.2017.003

Joanna Falkowska, Dorota Grabowska-Pieńkosz

Wydział Nauk Pedagogicznych UMK Toruń

\title{
MYŚL PEDAgogiczNA \\ W BADANIACH NAUKOWYCH \\ TORUŃSKICH HISTORYKÓW WYCHOWANIA
}

\section{Wstęp}

ワToruńska historia wychowania związana jest z wykształceniem — i doświadczeniami zawodowymi osób, którzy ją tworzyli. Byli to zarówno historycy, filozofowie, jak i pedagodzy, którzy prowadzili wykłady i seminaria z tego zakresu. Trzeba zaznaczyć, że w Toruniu nie było zaplecza instytucjonalnego historii wychowania, jedynie w 1945 r. powołano Katedrę Pedagogiki, która funkcjonowała w strukturach Wydziału Humanistycznego Uniwersytetu Mikołaja Kopernika. Warto wspomnieć, że w początkowym okresie organizowania struktur uniwersytetu, w tym poszczególnych katedr, pojawił się pomysł utworzenia katedry historii wychowania, a - co ważniejsze - Stanisław Łempicki rozmyślał o możliwości pracy w murach toruńskiej Alma Mater. Jak zaznaczyła Władysława Szulakiewicz, otrzymał on propozycję objęcia Katedry Historii Oświaty i Szkolnictwa ${ }^{1}$. Jednak miał pewne wątpliwości związane z tą propozycją, o czym świadczą

1 W. Szulakiewicz, Historia oświaty $i$ wychowania $w$ Polsce 1944-1956, Kraków 2006, s. 60. 
słowa skierowane w liście z dnia 3 września 1945 r. do swego przyjaciela Ludwika Kolankowskiego, pierwszego rektora UMK. Pisał tak: „Ja może utrzymam się w Krakowie na katedrze literatury polskiej starszej. Jest to bardzo prawdopodobne. Decyzja zapadnie niedługo. W każdym razie i mnie nie skreślaj drogi Ludwiczku z listy toruńskiej przy katedrze historii oświaty i szkolnictwa lub literatury polskiej starszej"2. Ostatecznie zdecydował się na pracę na Uniwersytecie Jagiellońskim. Ponowny pomysł związany z instytucjonalizacją historii wychowania pojawił się w roku akademickim 1948/1949. Wówczas w ramach działalności Instytutu Historii planowano powołać Katedrę Historii Oświaty i Wychowania, lecz z powodu trudności wynikających z pozyskania profesorów nie można było zrealizować tych zamierzeń ${ }^{3}$.

\section{Początki badań nad myślą pedagogiczną}

Początki badań prowadzonych nad myślą pedagogiczną w ośrodku toruńskim związane są z osobą prof. dr Kazimierza Sośnickiego, który jesienią 1945 r. wraz z grupą lwowskich profesorów przybył do Torunia i współtworzył struktury powstającego uniwersytetu ${ }^{4}$. Od pierwszych lat działania Katedry Pedagogiki objął on funkcję kierownika, a asy-

2 Powstanie i pierwsze dziesięć lat UMK 1945-1956, wybór źródeł, wyd. H. Duczkowska-Moraczewska, Toruń 1995, s. 41.

3 B. Nadolski, Wydział Humanistyczny, w: Uniwersytet Mikołaja Kopernika 1945-1955, red. R. Galon, Warszawa 1957, s. 41.

${ }^{4}$ W połowie lipca 1945 r. działalność rozpoczął Wydział Humanistyczny, a w listopadzie 1945 r. K. Sośnicki wraz z grupą lwowskich profesorów przybył do Torunia, gdzie objął Katedrę Pedagogiki. W roku akademickim 1945/1946 był prodziekanem Wydziału Humanistycznego UMK. Sośnicki Katedrą kierował przez 15 lat, aż do czasu przejścia na emeryturę w 1960 r. Wówczas Katedrę objął prof. dr hab. Ludwik Bandura, lecz z powodu braku odpowiedniej liczby samodzielnych pracowników naukowych zawieszono nabór na studia pedagogiczne. Wielu nauczycieli akademickich zatrudnionych w katedrach pedagogiki i psychologii było zmuszonych odejść z powodu redukcji etatów, m.in.: Stefan Wołoszyn, Lidia Wołoszynowa, Stanisław Gerstmann czy Andrzej Lewicki. Rekrutację na studia pedagogiczne wznowiono dopiero w $1973 \mathrm{r}$. 
stentami w Katedrze byli mgr Kazimierz Moroz oraz mgr Stefan Wołoszyn. Sośnickiego śmiało można uznać za jednego z najwybitniejszych twórców polskiej pedagogiki, który na Uniwersytecie Mikołaja Kopernika w Toruniu stworzył po II wojnie światowej liczący się ośrodek naukowy. Warto wspomnieć, że Katedra kierowana przez Sośnickiego współpracowała z Katedrą Filozofii, Psychologii, z Towarzystwem Filozoficznym, a także z Katedrą Pedagogiki funkcjonującą na Uniwersytecie Warszawskim ${ }^{5}$. Była to zatem współpraca uczniów i kontynuatorów myśli Kazimierza Twardowskiego, m.in.: Kazimierza Sośnickiego, Tadeusza Czeżowskiego, Andrzeja Lewickiego, Bogdana Nawroczyńskiego. Jak określił to Stanisław Nalaskowski, „Uczonych tych łączył ideał naukowy Szkoły Filozoficznej Lwowsko-Warszawskiej”6.

K. Sośnicki wyróżniał się rozległymi zainteresowaniami naukowymi. W swojej działalności nauczycielskiej i naukowej zajmował się zagadnieniami z zakresu logiki, metodologii, pedagogiki ogólnej, dydaktyki oraz teorii wychowania7. Poza tym wiele jego publikacji naukowych było przenikniętych treściami filozoficznymi, natomiast w badaniach naukowych uczony posługiwał się metodą analizy filozoficznej. Jeśli chodzi o myśl pedagogiczną, to uczony opublikował pracę pt. Rozwój pedagogiki zachodniej na przełomie XIX i XX wieku (1967). Książka ta jest w pewnej mierze pracą historyczną, ponieważ zawiera porównanie kierunków i systemów pedagogicznych powstałych w latach 1870-1960. Sośnicki scharakteryzował takie systemy i kierunki, jak: szkołę tradycyjną, nowe wychowanie, pedagogikę eksperymentalną, pedago-

5 S. Nalaskowski, Początki pedagogiki i jej rozwój w latach 1945-2000 widziane oczami Nestora, w: Pedagogika toruńska: od katedry do wydziału, S. Nalaskowski, W. Szulakiewicz, Toruń 2009, s. 15.

6 Tamże.

7 Wśród prac należy wymienić: Pedagogika ogólna, Toruń 1949; Dydaktyka ogólna, Warszawa 1959; Istota i cele wychowania, Warszawa 1967; Teoria środków wychowania, Warszawa 1973; Podstawy wychowania państwowego, Lwów-Warszawa 1931; Wychowanie intelektualne, Warszawa 1936; Początki logiki: ksią̇ka dla miłośników rozrywek umysłowych, Toruń 1948; Zarys dydaktyki: podręcznik dla użytku seminariów nauczycielskich i nauczycieli, Lwów 1925; Wskazówki do rozwiązania zadań logicznych zawartych w „Zarysie logiki”, Lwów 1926; Ogólne założenia podręczników szkolnych, Warszawa 1962. 
gikę kultury czy pedagogikę społeczną. W przygotowanej recenzji Bogdan Nawroczyński podkreślił: „Cenny podarek otrzymaliśmy od profesora Kazimierza Sośnickiego jest nim książka o rozwoju pedagogiki zachodniej od Herbarta aż po angielskich egzystencjalistów, doprowadzona do 1960 roku. [...] Warto w jego książce przeczytać zwłaszcza rozdział zatytułowany: <Uwagi o pedagogice neoidealizmu>, aby się nacieszyć maestrią, z jaką to czyni"8. Należy podkreślić, że Kazimierz Sośnicki był uczonym o wielkim autorytecie moralnym i naukowym, wyróżniał się wszechstronną wiedzą, krytycyzmem, jak i zarazem samokrytycyzmem, rzetelnością opisu i wyjaśniania złożonych problemów, będących przedmiotem jego zainteresowań.

Kolejną osobą, która podjęła się badań nad polską myślą pedagogiczną w Katedrze Pedagogiki na Uniwersytecie Mikołaja Kopernika w Toruniu była Jadwiga Lechicka9 . Od 1946 r. jako adiunkt wykładała historię oświaty i wychowania, a także dydaktykę historii i historię organizacji szkolnictwa na nowo powstałym uniwersytecie. Początkowo seminaria prowadziła wspólnie z K. Sośnickim, a dopiero od 1954 r. samodzielnie, a problematyka zajęć dotyczyła sytuacji oświaty i kultury w Polsce, przede wszystkim w okresie Oświecenia. W Toruniu zorganizowała też sekcję dydaktyczną przy miejscowym oddziale Polskiego Towarzystwa Historycznego i przez kilka następnych lat kierowała jej pracami. Zainteresowania naukowe J. Lechickiej obejmowały przede wszystkim historię oświaty doby Oświecenia, a w szczególności badaczka zajęła się analizą relacji historii kultury z wydarzeniami

8 B. Nawroczyński, Recenzja książki K. Sośnickiego „Rozwój pedagogiki zachodniej na przełomie XIX i XX wieku”, „Nowa Szkoła” 1968, nr 4, s. 57.

9 J. Lechicka w 1947 r. habilitowała się z dydaktyki historii i historii nowożytnej na podstawie pracy Dydaktyka historii, od 1951 r. pracowała jako docent, zaś w 1957 r. została mianowana profesorem nadzwyczajnym. W 1962 r. objęła kierownictwo Katedry Historii Polski i Powszechnej XV-XVIII wieku. W latach 1954-1958 była kolejno prodziekanem i dziekanem Wydziału Humanistycznego UMK. Została odznaczona Krzyżem Oficerskim Orderu Odrodzenia Polski. Szerzej: O. Nikonowicz, Lechicka Jadwiga - historyk, prof. UMK, w: Toruński słownik biograficzny, t. 1, Toruń 1998; J. Serczyk, Jadwiga Lechicka (16 X 1898-20 IV 1965), „Kwartalnik Historyczny” 1965, z. 4; A. Tomczak, Jadwiga Lechicka jako pedagog i działacz społeczny, „Zapiski Historyczne” 1966, t. 31, z. 4. 
politycznymi. Jej twórczość pisarska z zakresu historii wychowania i myśli pedagogicznej dotyczy przede wszystkim problematyki instytucji oświatowych na ziemiach polskich, a także osób zaangażowanych w ich rozwój. Wśród jej ważniejszych publikacji można wymienić: Źródła do dziejów Akademii Chetmińskiej: 1386-1815 (1963), Rola dziejowa Stanisława Leszczyńskiego oraz wybór z jego pism (1951), Józef Wybicki: życie i twórczość (1962), Z zagadnień oświecenia na Pomorzu (1957), Kultura i szkolnictwo $w$ czasach saskich, w: Historia wychowania, red. Ł. Kurdybacha, t. 1 (1965), Odgłosy strajku szkolnego w r. 1905 wśród młodzieży galicyjskiej, w: Walka o szkołę polska („Zapiski TNT" 1949, t. 15). J. Lechicka była również autorką prac z zakresu dydaktyki historii ${ }^{10}$.

Jednak do twórców toruńskiego środowiska historyków wychowania, którzy w znaczący sposób przyczynili się do rozwoju i usystematyzowania badań nad polską myślą pedagogiczną, należy zaliczyć działalność prof. dr hab. Bolesława Pleśniarskiego. Kiedy w roku 1976/1977 Katedrę przekształcono w Instytut Pedagogiki i Psychologii ${ }^{11}$, to w jego ramach utworzono jednostki, a wśród nich powstał Zakład Historii i Teorii Wychowania, gdzie kontynuowano badania naukowe i prowadzono zajęcia z zakresu historii wychowania. Pracami Instytutu kierował do 1978 r. B. Pleśniarski, zaś w latach 1976-1978 zarządzał on Zakładem. Ten historyk wychowania, uczeń Ludwika Jaxy-Bykowskiego $^{12}$, w 1959 r. obronił rozprawę doktorską pt. Zagadnienia oświatowe i wychowawcze w czasopiśmiennictwie Wielkiego Księstwa Poznańskiego

10 Wśród prac należy wymienić: Polska dydaktyka historii w latach 1925-1937, Łódź 1937; Znaczenie wychowawcze geografii i nauki o Polsce współczesnej, Łódź 1932; Historia: dla I kl. liceum. Cz. 1, Grecja, Rzym i wieki średnie do 1300 r., Lwów 1938; Historia: dla I kl. liceum. Cz. 2, Dzieje wieków średnich, dzieje nowożytne do 1660 r., Lwów 1938; Realizacja poczynań wychowawczych na terenie okręgu szkolnego łódzkiego, Łódź 1932.

11 Instytut Pedagogiki i Psychologii funkcjonował do 1990 r., a następnie został przekształcony w Instytut Pedagogiki. Bolesław Pleśniarski był dyrektorem Instytutu w latach 1969-1976.

12 B. Pleśniarski (1908-1987) na UMK pracował w latach 1951-1986. Studiował pod kierunkiem L. Jaxy-Bykowskiego. Natomiast pracę doktorską obronił pod kierunkiem Stefana Truchima. 
w latach 1815-1847, napisaną pod kierunkiem zasłużonego historyka kultury, oświaty i szkolnictwa Stefana Truchima ${ }^{13}$.

Dzięki zaangażowaniu w pracę naukową B. Pleśniarski przyczynił się do rozwoju historii wychowania, a także promował historyków wychowania. Poza tym należy zaznaczyć, że w toruńskim środowisku zapoczątkował on znaczące badania poświęcone historii myśli pedagogicznej. Jego zainteresowania badawcze koncentrowały się wokół pedagogiki, historii wychowania i myśli pedagogicznej. W szczególności zajął się analizą sytuacji szkolnictwa w Wielkopolsce w XIX w., w nawiązaniu do stosunków społeczno-gospodarczych Księstwa Warszawskiego. Do ważniejszych publikacji profesora należy zaliczyć: Szkolnictwo departamentu bydgoskiego $w$ okresie Księstwa Warszawskiego (1965), Poglądy Wielkopolan na sprawy wychowawcze i oświatowe $w$ świetle prasy Wielkiego Księstwa Poznańskiego: 1814-1847 (1962); O racjonalizm i postep: $z$ prac programowych i praktyki Komisji Edukacji Narodowej (1973). Kolejny obszar badań podejmowanych przez Pleśniarskiego nad myślą pedagogiczną dotyczył okresu okupacji hitlerowskiej, a przede wszystkim tajnej oświaty, co zaprezentował w pracach: Wychowanie w Gwardii i Armii Ludowej (1973) oraz Koncepcje oświaty powojennej w programach polskiej konspiracji 1939-1945 (1982). Interesował się również dziejami laicyzacji oświaty i myśli pedagogicznej. Podstawową pracą poświęconą tej problematyce jest Zarys historii laicyzacji oświaty wychowania w Polsce (1961). Ponadto był współautorem i redaktorem takich publikacji, jak: Gimnazjum Polskie i Liceum Ogólnokształcące w Kwidzynie (1937-1939, 1945-1977) (1980), Antoni Makarenko w szkole wyższej (1974) czy Mikołaj Kopernik: materiały na obchody kopernikowskie dla szkół i placówek pozaszkolnych (1972). Trzeba podkreślić, że były to prace dotyczące dziejów oświaty polskiej w XIX i XX w., a także instytucji, w tym szkół różnych szczebli.

13 G. Karłowska, Bolesław Pleśniarski (1908-1987), w: Słownik biograficzny polskiej historii wychowania, red. A. Meissner i W. Szulakiewicz, Toruń 2008, 654-655; P. Kowalik, Wspomnienia o profesorze dr hab. B. Pleśniarskim (1908-1987), „Chowanna” 1987, z. 4, s. 481-482; T. Wróblewska, Bolesław Pleśniarski 1908-1987, „Przegląd Historyczno-Oświatowy” 1989, nr 3, s. 313-317. 
Badaniami naukowymi nad myślą pedagogiczną w toruńskim środowisku zajmował się również prof. dr hab. Jerzy Danielewicz, który w latach 1984-1987 pełnił funkcję dyrektora Instytutu Pedagogiki i Psychologii, zaś w latach 1984-1991 był kierownikiem Zakładu Historii Oświaty i Wychowania. Ponadto zaangażowany był w prace wielu organizacji i towarzystw naukowych, m.in. Polskiego Towarzystwa Historycznego. Jego zainteresowania badawcze dotyczyły historii Polski i historii powszechnej XIX i XX w., a także historii oświaty. Był autorem wyboru pism politycznych Joachima Lelewela, opublikował materiały dotyczące dziejów szkolnictwa Ziemi Gdańskiej¹4.

\section{Badania nad społeczną myślą wychowania w latach 1991-2000}

Badania naukowe prowadzone przez toruński ośrodek historyków wychowania w latach $90 . \mathrm{XX}$ w. zostały poświęcone analizie społecznej myśli wychowania. Problematyka ta stała się przedmiotem zainteresowania pracowników naukowych Zakładu Historii Wychowania i Myśli Społecznej w Instytucie Pedagogiki UMK w Toruniu, którym w latach 1991-1996kierowałprof.drhab.AndrzejWojtas.Dozespołubadawczego wówczas należeli również: dr Witold Wojdyło ${ }^{15}$, dr Michał Strzelecki ${ }^{16}$,

14 Wybór pism politycznych. Joachim Lelewel, wybór i przyp. opatrzyli Wł. Bortnowski, J. Danielewicz, red. i ze wstępem M.H. Serejskiego, Warszawa 1954; Materiały z dziejów szkolnictwa Ziemi Gdańskiej, red. J. Danielewicz, Gdańsk 1968.

15 Witold Wojdyło - absolwent historii na UMK. W 1981 r. zdobył stopień doktora za pracę pt. Bataliony Chłopskie. Oddziały specjalne i partyzanckie. Od 1985 r. zatrudniony na UMK. W 1993 r. uzyskał stopień doktora habilitowanego nauk humanistycznych w zakresie historii na podstawie pracy pt. Koncepcje społeczno-polityczne Stanisława Grabskiego, zaś w 2004 r. tytuł profesora. Pełnił obowiązki dziekana Wydziału Humanistycznego UMK, a w latach 2008-2012 objął funkcję prorektora ds. studenckich na UMK. Obecnie kierownik Katedry Myśli Politycznej na Wydziale Politologii i Studiów Międzynarodowych na UMK.

16 Michał Strzelecki - absolwent historii na UMK, w 1994 r. uzyskał stopień doktora na podstawie rozprawy pt. Działalność opozycji parlamentarnej w Krajowej Radzie Narodowej i Sejmie Ustawodawczym (VI 1945-X 1947). W 2009 r. ha- 
dr Adam Marszałek ${ }^{17}$ i mgr Lucjan Broniewicz ${ }^{18}$. Ich działalność naukowo-badawcza poświęcona była analizie idei wychowania społecznego w różnych ugrupowaniach ideowo-politycznych w okresie dwudziestolecia międzywojennego, a także w trakcie II wojny światowej i po jej zakończeniu. Wychowanie społeczne rozumiano jako „długotrwałe, świadome i celowe i wielopłaszczyznowe działanie na rzecz rozwijania $\mathrm{w}$ jednostkach systemu wartości i norm pogłębiania poziomu identyfikacji z określoną wspólnotą, upowszechniania pożądanych oraz uwzględniających istniejące realia wzorów aktywności w przestrzeni publicznej, jak również ich przygotowania do wypełniania określonych ról"19.

W ramach prowadzonych badań nad problematyką wychowania społecznego w polskiej myśli pedagogicznej XX w. pracownicy Zakładu Historii Wychowania i Myśli Społecznej pozyskali grant badawczy Komitetu Badań Naukowych pt. „Wychowanie społeczne w koncepcjach politycznych i społecznych w Drugiej Rzeczypospolitej", którego kierownikiem i koordynatorem był Andrzej Wojtas. Projekt był realizowany przez dwa lata w okresie 1992-1994. Wyniki badań zo-

bilitował się na podstawie pracy Wizje wychowania społecznego $w$ polskiej myśli politycznej lat 1918-1939, a w 2012 r. otrzymał tytuł profesora nadzwyczajnego UMK w Toruniu. W latach 1997-2010 był pracownikiem Instytutu Nauk Politycznych Uniwersytetu Kazimierza Wielkiego w Bydgoszczy. Od 2010 r. pracownik Wydziału Politologii i Studiów Międzynarodowych UMK w Toruniu. W latach 2010-2016 prodziekan Wydziału Politologii i Studiów Międzynarodowych UMK ds. nauki i współpracy z zagranicą.

17 Adam Marszałek - pracował w Instytucje Filozofii na Wydziale Humanistycznym UMK, w 1990 r. założył w Toruniu Wydawnictwo Adam Marszałek, którym kierował do 2013 r., a od 1 stycznia 2013 r. funkcję prezesa Wydawnictwa pełni prof. dr hab. Joanna Marszałek-Kawa.

${ }^{18}$ Lucjan Broniewicz - absolwent wydziału historycznego UMK, od $1987 \mathrm{r}$. pracował w Instytucie Nauk Społecznych UMK, następnie w Instytucie Pedagogiki UMK. W 1993 r. objął stanowisko dyrektora zarządzającego Planetarium im. Władysława Dziewulskiego, którym zarządzał aż do śmierci (2012). Uczestniczył w życiu społecznym Torunia oraz w zespołach przygotowujących strategie rozwoju i promocji miasta.

19 W. Wojdyło, Toruński ośrodek badań naukowych $w$ dziedzinie historii wychowania w latach 1991-2000. Reminiscencje osobiste, „Acta Universitatis Nicolai Copernici. Pedagogika" 2015, nr 31, z. 426, s. 87. 
stały zaprezentowane $\mathrm{w}$ pracy pt. Polityka a wychowanie. Szkice z historii wychowania społecznego w Polsce, która ukazała się pod redakcją A. Wojtasa w 1994 r. nakładem Wydawnictwa Adam Marszałek. Publikacja ta zawiera artykuły badaczy m.in. z toruńskiego ośrodka historii wychowania. A. Wojtas przygotował dwa artykuły: Polityka a wychowanie oraz Nurt etyczny wychowania społecznego w Polsce, M. Strzelecki Wychowanie w myśli społeczno-politycznej ruchu ludowego w Drugiej Rzeczypospolitej, zaś W. Wojdyło Wychowawcze aspekty myśli politycznej obozu demokratyczno-narodowego 1918-1928. Z kolei dalsze badania podejmowane w Zakładzie Historii Wychowania i Myśli Społecznej koncentrowały się na poznaniu relacji między założeniami ideowymi oraz działalnością polskich ugrupowań i stronnictw politycznych $\mathrm{XX}$ w., a także wysuwanymi przez nie koncepcjami oświatowymi, wychowawczymi. Wówczas wychowanie rozumiano jako istotny element polityki i zachodzących transformacji społecznych ${ }^{20}$.

Badania nad społeczną myślą wychowania były kontynuowane po odejściu prof. dr hab. Andrzeja Wojtasa w 1996 r. do innego ośrodka naukowego - Wyższej Szkoły Pedagogicznej w Bydgoszczy (obecnie Uniwersytet Kazimierza Wielkiego). Wówczas funkcję kierownika Zakładu objął prof. dr hab. W. Wojdyło i sprawował ją do roku 2000, a zespół badawczy tworzyli: dr Michał Strzelecki, mgr Jarosław Góralski, mgr Katarzyna Kalinowska ${ }^{21}$. W. Wojdyło kontynuował problematykę zapoczątkowaną przez poprzednika, czyli społeczno-polityczny nurt historii wychowania. Jego zainteresowania naukowe koncentrowały się na kilku zagadnieniach. Tematyce dotyczącej procesów kształtowania świadomości narodowej i politycznej narodu polskiego w XIX i początkach XX w. poświęcił następujące publikacje: Wychowanie jako forma działania politycznego w myśli społeczno-politycznej Obozu Narodowego na terenie zaboru pruskiego do 1914 roku (1997), Wychowanie jako forma działalności społeczno-politycznej Stronnictwa Demokratyczno-Narodowego w Galicji do roku 1914 (1997). Przedmiotem analizy uczynił też idee społeczno-wychowawcze powstałe w Drugiej

20 Tamże, s. 90-91.

21 Katarzyna Kalinowska (1973-2009) - w latach 1997-2009 pracownik naukowo-dydaktyczny UMK. 
Rzeczypospolitej, co można odnaleźć w książkach: Koncepcje społeczno-polityczne Stanisława Grabskiego (1993), Wychowanie jako forma działania politycznego $w$ myśli społeczno-politycznej Obozu Narodowego w latach 1926-1939 (1999), Koncepcje reform oświatowych w myśli społeczno-politycznej obozu narodowego Drugiej Rzeczypospolitej: projekt reformy szkolnictwa Ministra Wyznań Religijnych i Oświecenia Publicznego Stanisława Grabskiego z 1925 roku (1995). Ponadto Wojdyło zbadał wzajemne relacje między polityką a wychowaniem, głównie wychowaniem narodowym. Problematyce tej poświęcił prace: Funkcja mitu w koncepcjach wychowania narodowego (1996), Naród, charakter narodowy, wychowanie narodowe w koncepcjach społeczno-politycznych Stanisława Grabskiego w latach 1918-1939 (1993).

Kolejny członek z zespołu badawczego - Michał Strzelecki zajmował się analizą znaczenia wychowania społecznego w XX w. W szczególności zaprezentował koncepcje kształtowania społeczeństwa obywatelskiego w myśli społeczno-politycznej ruchu ludowego, czego przykładem mogą być prace: Wychowanie jako instrument budowy demokratycznego państwa $w$ myśli społeczno-politycznej ruchu ludowego w latach 1918-1947 (1997) oraz Wizje wychowania społecznego w polskiej myśli politycznej lat 1918-1939 (2008). Poza tym zaprezentował działalność legalnych środowisk opozycyjnych po II wojnie światowej w publikacjach: Wychowanie samorządowe $w$ koncepcjach i działalności opozycji parlamentarnej w latach 1945-1947 (1995) oraz Koncepcje oświatowo-wychowawcze legalnej opozycji politycznej w latach 1945-1947 (1993). M. Strzelecki przedmiotem zainteresowań uczynił także koncepcje społeczeństwa polskiego w myśli politycznej, a potwierdzeniem mogą być prace: Wizerunek społeczeństwa polskiego w myśli politycznej piłsudczyków w latach 1918-1935 (2000), Wątki narodowe i państwowe $w$ katolickiej koncepcji wychowania społecznego w okresie Drugiej Rzeczypospolitej (1999). Z kolei Jarosław Góralski skoncentrował się na analizie działalności organizacji oświatowo-wychowawczej Polskiej Macierzy Szkolnej. Tematyce tej poświęcił dwie publikacje - Polska Macierz Szkolna jako instytucja wychowania obywatelskiego (1999) oraz Wizerunek działacza kulturalno-oświatowego w poglądach reprezentantów Polskiej Macierzy Szkolnej do roku 1939 (2000). Natomiast Katarzyna Kalinowska przedmiotem dociekań ba- 
dawczych uczyniła działalność ojca Jacka Woronieckiego. Problematykę tę zaprezentowała w publikacjach: Idea państwa $w$ myśli społecznej o. Jacka Woronieckiego (1999), Społeczeństwo a stereotypy w myśli społecznej o. Jacka Woronieckiego (2000), Jacek Woroniecki o społeczeństwie i państwie (2005).

Podejmowane w Zakładzie Historii Wychowania i Myśli Społecznej badania naukowe nad społeczną myślą wychowania były również poddawane pod dyskusję podczas organizowanych konferencji naukowych. Pierwszą w tym zakresie inicjatywą była interdyscyplinarna konferencja naukowa nt. Wychowanie a polityka. Tradycja i współczesność, która odbyła się w dniach 7-8 listopada 1996 r. Uczestnicy tego spotkania reprezentowali różne ośrodki akademickie oraz dziedziny naukowe, bo poza środowiskiem historyków wychowania uczestniczyli również pedagodzy, socjologowie, filozofowie, historycy myśli politycznej oraz historycy literatury, co przyczyniło się do interdyscyplinarnego zaprezentowania problematyki podejmowanej dyskusji. Tematyka relacji między wychowaniem a polityką była kontynuowana podczas kolejnych konferencji naukowych zorganizowanych w latach 1996-2008. Efektem tego rodzaju spotkań naukowych było wydanie 5 prac zbiorowych. Pierwsza z nich - Wychowanie a polityka. Tradycja i wspótczesność ukazała się w 1997 r. pod redakcją W. Wojdyły i M. Strzeleckiego. Kolejne dwie ukazały się pod redakcją W. Wojdyły: w 1999 r. Wychowanie a polityka: między wychowaniem narodowym a państwowym, zaś w 2000 r. Wychowanie a polityka: mity i stereotypy w polskiej myśli społecznej XX wieku. Z kolei w 2004 r. wydana została książka Wychowanie a polityka: cele polityczne jako czynnik determinujący oddziaływanie wychowawcze, której redaktorami byli G. Radomski i Katarzyna Kalinowska. Ta ostatnia objęła również redakcję nad kolejną publikacją: Wychowanie a polityka: kultura polityczna a kształtowanie tożsamości społeczeństwa polskiego, która ukazała się w 2008 r. $^{22}$.

Organizowane przez środowisko toruńskich historyków wychowania konferencje naukowe poświęcone polskiej myśli pedagogicznej stały się doskonałą okazją do nawiązania współpracy z historykami

${ }^{22}$ W. Wojdyło, dz. cyt., s. 92. 
wychowania z różnych ośrodków akademickich, m.in. z: Uniwersytetu Adama Mickiewicza, Uniwersytetu Szczecińskiego, Uniwersytetu Wrocławskiego, Uniwersytetu Warszawskiego, Uniwersytetu Gdańskiego, Uniwersytetu Łódzkiego, Uniwersytetu Kazimierza Wielkiego, Uniwersytetu w Zielonej Górze, Wyższą Szkołą Pedagogiczną w Rzeszowie i Wyższą Szkołą Pedagogiczną w Słupsku. Na tego rodzaju spotkania zapraszano również pedagogów, historyków, filozofów, socjologów oraz politologów, co zapewniało interdyscyplinarne spojrzenie na zagadnienia dotyczące oświaty. Zatem należy podkreślić, że głównym celem działalności naukowej członków Zakładu Historii Wychowania i Myśli Społecznej Instytutu Pedagogiki było stworzenie istotnego ośrodka w zakresie badań nad historią wychowania XX stulecia, a zwłaszcza w kontekście relacji między szeroko rozumianą problematyką oświatowo-wychowawczą a polityką.

\section{Kierunki badań nad myślą pedagogiczną w latach 2002-2017}

Kolejne zmiany w zakresie tematyki prowadzonych badań nad myślą pedagogiczną przez toruńskich historyków wychowania miały miejsce po 2000 r., a dokładniej, kiedy w 2002 r. kierownikiem Zakład Historii Edukacji została Władysława Szulakiewicz. Zakład ten funkcjonował do roku akademickiego 2007/2008, a następnie historycy wychowania zajmujący się badaniem dziejów myśli pedagogicznej weszli w skład zespołu nauczycieli akademickich tworzących Katedrę Pedagogiki, kierowaną przez W. Szulakiewicz. Katedra ta skupiała reprezentantów kilku subdyscyplin pedagogicznych, co nie sprzyjało koncentrowaniu się na prowadzeniu badań historyczno-oświatowych. Dopiero w 2013 r. nastąpiło usamodzielnienie się toruńskich historyków wychowania, ponieważ została powołana Katedra Historii Myśli Pedagogicznej, a jej skład osobowy tworzą pracownicy zajmujący się jedynie dziejami oświaty i wychowania.

Kierunki badań podejmowanych przez pracowników Katedry w zakresie myśli pedagogicznej obejmują kilka obszarów, zaś wyniki badań były prezentowane $\mathrm{w}$ różnych formach - w postaci monografii na- 
ukowych, artykułów czy referatów prezentowanych na konferencjach naukowych. Jednym $\mathrm{z}$ nich jest biografistyka pedagogiczna ${ }^{23}$. Wiele miejsca poświęcono na przygotowanie biografii osób zasłużonych w dziejach rozwoju polskiej myśli pedagogicznej. A wśród nich można wymienić takie nazwiska, jak: Stanisław Łempicki ${ }^{24}$, Kazimierz Twardowski ${ }^{25}$, Anastazja Dzieduszycka ${ }^{26}$, Wanda Szuman ${ }^{27}$, Elżbieta Zawacka ${ }^{28}$. Ponadto należy wspomnieć o opracowanym pod redakcją Andrzeja Meissnera i Władysławy Szulakiewicz Słowniku biograficznym polskiej historii wychowania (2008). Przygotowany został pod patronatem Towarzystwa Historii Edukacji i zawiera ponad 200 biogramów zasłużonych historyków wychowania od końca XVIII do XX w.,

23 Badania biograficzne $w$ pedagogice: studia źródłowe i bibliograficzne, red. W. Szulakiewicz, Toruń 2015.

24 W. Szulakiewicz, Stanisław Łempicki (1886-1947: twórca lwowskiej szkoły historii wychowania, Toruń 2012; tejże, Stanisław Łempicki (1886-1947), w: Złota księga historiografii lwowskiej XIX i XX wieku, red. J. Maternicki, przy współpr. L. Zaszkilniak, Rzeszów 2007.

25 W. Szulakiewicz, Istota i zakres dydaktyki ogólnej w Szkole Kazimierza Twardowskiego (Kazimierz Twardowski - Kazimierz Sośnicki - Bogdan Nawroczyński), w: Inspiracje dla wspótczesnej edukacji w dydaktyce Drugiej Rzeczypospolitej, red. D. Drynda, Katowice 2000; tejże, Rodzina w życiu wybitnych uczonych: przykład Kazimierza Twardowskiego (1866-1938), w: Obrazy rodziny w ujęciu pedagogicznym i historycznym, red. A. Szerląg, S. Walasek, Wrocław 2012; tejże, Nauczyciel $w$ twórczości $i$ działalności pedagogicznej Kazimierza Twardowskiego, „Przegląd Historyczno-Oświatowy” 2014, nr 1-2.

26 J. Falkowska, „Przeciw marzycielstwu”. Działalność edukacyjna Anastazji z Jełowickich Dzieduszyckiej (1842-1890), Toruń 2014; tejże, O powinnościach nauczycielek szkół ludowych: poglądy Anastazji z Jełowickich Dzieduszyckiej (1842-1890), „Przegląd Historyczno-Oświatowy” 2013, nr 3-4; tejże, Pochwała pracy: Anastazji Dzieduszyckiej pozytywistyczna idea emancypacji kobiet, w: W stulecie śmierci Jana Władysława Dawida, red. H. Markiewiczowa, Warszawa 2014; tejże, Kobieta $w$ roli matki: propozycje Anastazji z Jełowickich Dzieduszyckiej (1842-1890), „Wychowanie w Rodzinie” 2015, t. 12.

27 A. Wałęga, Życie i działalność Wandy Szuman (1890-1994), Toruń 2005.

${ }^{28}$ R. Borowicz, H. Kostyło, W. Szulakiewicz, Elżbieta Zawacka-Zoo. Portret akademicki, Toruń 2009; W. Szulakiewicz, Biografia pedagogiczna Elïbiety Zawackiej (1909-2009), w: Prof. dr hab. gen. bryg. Elżbieta Zawacka (1909-2009): materiały do biografii, red. K. Minczykowska, Toruń 2010. 
uwzględniając ich wykształcenie i prowadzone badania nad dziejami oświaty, twórczość pisarską oraz działalność organizatorską. Przyjęto, że „Historykiem wychowania jest każdy, kto prowadzi badania naukowe w dziedzinie historii oświaty i wychowania, zajmuje się w sposób fachowy edytorstwem źródeł historycznych i naukową informacją w tej dziedzinie, upowszechnia w druku wiedzę o przeszłości oświatowej, uprawia ogólniejszą refleksję nad historią wychowania i jej nauczaniem, a także organizuje warsztat badań historyczno-oświatowych" 29 . Na tej podstawie opracowano zbiorową biografię polskiej historii wychowania, będącą wartościowym źródłem dla osób prowadzących badania naukowe w tym zakresie, jak i wszystkich tych, którzy interesują się historią oświaty i wychowania, a w szczególności jej twórcami.

Zakres badań prowadzonych nad myślą pedagogiczną w ośrodku toruńskim dotyczy również ukazania wartości źródeł wykorzystywanych przez historyków wychowania. Dlatego wiele miejsca poświęcono metodologii badań historyczno-pedagogicznych. Przygotowane przez pracowników Katedry publikacje w tym zakresie zostały poświęcone sposobom zbierania i analizy różnego rodzaju źródeł historycznych. Skoncentrowano się na pokazaniu wartości źródeł opisowych, m.in.: biografii, pamiętników, wspomnień, korespondencji, czasopism, a także źródeł dokumentowych i aktowych, czyli przede wszystkim dokumentów i zbiorów akt powstałych w wyniku działalności urzędów, instytucji państwowych, społecznych oraz akt pochodzenia prywatnego. Uwzględniono również zasady postępowania badawczego w pracy historyków wychowania. Wśród publikacji poświęconych tej problematyce znajdują się artykuły w czasopismach i pracach zbiorowych ${ }^{30}$.

29 W. Szulakiewicz, Wstęp, w: Słownik biograficzny polskiej historii wychowania, red. A. Meissner, W. Szulakiewicz, Toruń 2008, s. 11-12.

30 W. Szulakiewicz, Ego-dokumenty $i$ ich znaczenie $w$ badaniach naukowych, „Przegląd Badań Edukacyjnych” 2013, nr 16; tejże, Korespondencja w badaniach historii edukacji i nauki, w: Badania historyczne w pedagogice: konteksty źródłowe, red. W. Szulakiewicz, Toruń 2015; A. Wałęga, „Szkoła” źródłem w badaniach historyczno-pedagogicznych polskich instytucji edukacyjnych doby zaborów, „Studia Paedagogica Ignatiana” 2016, Vol. 19, no 2; tejże, Galicyjska „Szkoła” jako przykład czasopisma pedagogicznego okresu zaborów, „Acta Universitatis Nicolai 
W zakresie analiz podejmowanych nad myślą pedagogiczną przez toruńskich historyków wychowania ważne miejsce zajmuje problematyka pedeutologii historycznej. Jak podkreślił znawca tej tematyki, zasłużony pedagog Antoni Smołalski, „pedeutologia historyczna jest próbą zrozumienia nauczyciela i nauczycielstwa dzisiejszego, jego aktualnego losu, poprzez doświadczenia czerpane z przeszłości i w miarę możliwości także przez przewidywanie przyszłości”31. Szczególnie ważnym kierunkiem badań pedeutologicznych w środowisku toruńskich historyków wychowania są wybrane koncepcje pedeutologiczne powstałe na przestrzeni XIX i XX w. w Polsce ${ }^{32}$. Zagadnienie to

Copernici. Pedagogika" 2013, nr 29, z. 406; tejże, Polskie podręczniki i wydawnictwa pomocnicze do historii wychowania okresu zaborów i II Rzeczypospolitej, Toruń 2011; J. Falkowska, Dzienniki Urzędowe c.k. Rady Szkolnej Krajowej jako źródło do dziejów oświaty w Galicji, w: Badania historyczne w pedagogice...; D. Grabowska, Wartość literatury pamiętnikarskiej $w$ badaniach pedeutologii historycznej, w: Badania historyczne w pedagogice...

31 A. Smołalski, Pedeutologia historyczna, Wrocław 2006, s. 8.

${ }^{32}$ Umieszczeni $w$ przeszłości. Pamięć $w$ naukach pedagogicznych, red. W. Szulakiewicz, Toruń 2016; W. Szulakiewicz, „O wychowaniu wychowawcy” światopogląd pedeutologiczny Józefa Ciembroniewicza (1877-1929), w: Amico, socio et viro docto: księga ku czci profesora Andrzeja Kazimierza Banacha, red. T. Pudłocki, K. Stopka, Kraków 2015; tejże, O edukacji pedagogicznej kobiet: Antoniny Machczyńskiej myśl pedeutologiczna, „Przegląd Historyczno-Oświatowy” 2015, nr 1-2; tejże, Jan Władysław Dawid w polskiej historiografii edukacyjnej: wybrane przykłady publikacji, w: W stulecie śmierci Jana Władysława Dawida...; D. Grabowska, Obraz nauczyciela okresu PRL w literaturze pamiętnikarskiej, w: Zaangażowanie? Opór? Gra? Szkice do portretu nauczyciela w latach PRL-u, red. R. Grzybowski, Torun 2013; tejże, Autorytet nauczyciela w źródłach autobiograficznych XIX wieku, w: Biografie nauczycieli i pedagogów. Idee - programy, red. R. Skrzyniarz, G. Bujak, K. Kołtuniewicz, Lublin 2013; tejże, „Przegląd Pedagogiczny” okresu II Rzeczypospolitej wobec projektów reform ksztatcenia nauczycieli, „Acta Universitatis Nicolai Copernici. Pedagogika" 2015, nr 31; D. Grabowska-Pieńkosz, Zapisani $w$ pamięci. Nauczyciele zaboru austriackiego $w$ literaturze pamiętnikarskiej, Toruń 2016; tejże, Nauczyciele zaboru austriackiego w literaturze pamiętnikarskiej, w: Umieszczeni w przeszłości...; D. Grabowska, J. Falkowska, Pamięć o wybitnych nauczycielach akademickich $i$ jej wpływ na ksztattowanie pogląów pedeutologicznych, „Acta Universitatis Nicolai Copernici. Pedagogika” 2013, nr 29, z. 406; J. Falkowska, Idee pedeutologiczne w szkole lwowsko-warszawskiej, „Studia Paedagogica Ignatiana" 2016, Vol. 19, no 2; A. Wałęga, Zagadnienia pedeutologiczne na łamach „Kwartalnika Pedagogicznego” (1956-1989), w: Zaangażo- 
rozwinęła W. Szulakiewicz w pracy pt. O uczących i uczonych. Szkice z pedeutologii historycznej (2014). Najważniejszym celem tej publikacji było odczytanie myśli pedeutologicznej w Szkole Lwowsko-Warszawskiej ${ }^{33}$. W pracy zaprezentowano portrety wybitnych twórców polskiej humanistyki, w perspektywie pojmowania przez nich służby nauczycielskiej. Ponadto ukazano style pracy pedagogicznej wybitnych uczonych, nauczycieli akademickich, którzy łączyli pracę naukową z działalnością dydaktyczną i oświatową. Istotnym elementem łączącym bohaterów tego opracowania jest wspólny rodowód akademicki i tworzenie przez nich szkoły naukowej skupiającej wielu równie cenionych uczniów. Do grona wybitnych uczonych W. Szulakiewicz zaliczyła: Kazimierza Twardowskiego, Ludwika Jaxa-Bykowskiego, Tadeusza Czeżowskiego oraz Izydorę Dąmbską. Zarysy portretów przedstawicieli tej szkoły filozoficznej dają wyobrażenie o zawodzie nauczyciela. Autorka pokazała także, jak wielki wpływ na styl pracy pedagogicznej i światopogląd pedeutologiczny miały doświadczenia edukacyjne wyniesione ze studiów uniwersyteckich, a także ze spotkań z wybitnymi uczonymi-mistrzami.

Jednym ze znaczących nurtów badań nad myślą pedagogiczną podejmowanych $\mathrm{w}$ toruńskim środowisku jest problematyka rozwoju polskiej historii oświaty i wychowania oraz historii pedagogiki. Nurt ten zaprezentowany został w pracach W. Szulakiewicz Historia oświaty i wychowania w Polsce 1918-1939: studium historiograficzne (2000) oraz Historia oświaty $i$ wychowania $w$ Polsce 1944-1956 (2006). W pierwszej z nich został przedstawiony portret środowiska historyków wychowania II Rzeczypospolitej, z uwzględnieniem ich zainte-

wanie? Opór? Gra?...; tejże, Nauczyciele galicyjscy w świetle „Szkoły”, w: Badania historyczne $w$ pedagogice...

33 Szkoła lwowsko-warszawska - grupa filozofów polskich działająca w I połowie XX w., hołdująca analizie filozoficznej języka jako metodzie filozoficznej, znana przede wszystkim z osiągnięć logicznych. Nazwy „szkoła lwowsko-warszawska" użył prawdopodobnie po raz pierwszy Kazimierz Ajdukiewicz w adresie powitalnym do uczestników Kongresu Filozofii Naukowej w 1935 r. w Paryżu. Początki szkoły wiążą się z działalnością K. Twardowskiego. Patrz: J. Woleński, Filozofia szkoły lwowsko-warszawskiej, Wrocław 1986; tenże, Szkoła Lwowsko-Warszawska w polemikach, Warszawa 1997. 
resowań badawczych i prezentowanych orientacji metodologicznych. $\mathrm{Z}$ kolei druga z wymienionych rozpraw została poświęcona rozwojowi polskiej historii oświaty i wychowania w latach 1944-1956. Okres ten obejmuje zarówno czas odbudowy życia naukowego, tworzenia nowych programów badawczych oraz organizacji ośrodków naukowych, ale także okres przyspieszonej sowietyzacji, ograniczania autonomii nauki i niszczenia naukowych instytucji.

Celem upowszechnienia wyników prowadzonych badań w zakresie historii myśli pedagogicznej, poza publikowaniem swoich prac, pracownicy Katedry Historii Myśli Pedagogicznej biorą udział w konferencjach naukowych organizowanych przez takie ośrodki akademickie, jak: Uniwersytet Adama Mickiewicza, Uniwersytet Wrocławski, Akademia Ignatianum w Krakowie, Uniwersytet Pedagogiczny w Krakowie, Uniwersytet Łódzki, Uniwersytet Warszawski, Akademia Pedagogiki Specjalnej w Warszawie, Uniwersytet w Białymstoku, Uniwersytet Szczeciński, Uniwersytet Gdański czy Katolicki Uniwersytet Lubelski. Poza tym staraniem toruńskich historyków wychowania zorganizowano na Wydziale Nauk Pedagogicznych UMK następujące konferencje naukowe: Badania historyczne w pedagogice. Konteksty źródłowe (8 grudnia 2014); Biografie pedagogiczne - konteksty źródłowe (11 maja 2015); Pamięć w pedagogice (1-2 marca 2016); Polska myśl pedagogiczna II połowy XX wieku i początków XXI wieku. Stan badań kierunki poszukiwań - projekty badawcze (6 grudnia 2016). Podjęto się również współorganizacji z Uniwersytetem Szczecińskim XIX Zjazdu Historyków Polskich w Szczecinie. W dniach 17-19 września 2014 r. odbywały się obrady historyków wychowania - sympozjum nt. Polskie reformy oświatowe $w$ nurcie europejskich przemian społecznych, politycznych $i$ kulturalnych.

\section{Zakończenie}

Podsumowując, badania naukowe prowadzone przez historyków oświaty i wychowania w Toruniu mają długoletnią tradycję. Jej początki nawiązują do idei zaczerpniętej ze Szkoły Lwowsko-Warszawskiej, zapoczątkowanej przez Kazimierza Twardowskiego, a kontynuowanej 
przez jego uczniów w różnych ośrodkach akademickich, w Toruniu przez Kazimierza Sośnickiego. Kierunki podejmowanych badań zależne były od wykształcenia i zainteresowań badawczych uczonych, a także zmian strukturalnych, jakie pojawiły się od momentu utworzenia Katedry Pedagogiki, funkcjonującej w ramach Wydziału Humanistycznego Uniwersytetu Mikołaja Kopernika w Toruniu. Z analizy wszystkich prac dotyczących myśli pedagogicznej podejmowanych przez badaczy toruńskiej historii wychowania należy podkreślić, że zakresem objęli czasy od dziejów Komisji Edukacji Narodowej po okres I poł. XX w. Początkowe publikacje autorów toruńskich z zakresu historii wychowania i myśli pedagogicznej dotyczyły instytucji oświatowych na ziemiach polskich, a także osób zaangażowanych w ich rozwój. Natomiast w kolejnych latach zakres prowadzonych badań uległ rozszerzeniu. Należy podkreślić zasługi toruńskich historyków wychowania podejmowane w zakresie analizy twórców historii myśli pedagogicznej XIX i początków XX w. Analizie poddane zostały również koncepcje oświatowe powstałe w okresie międzywojennym, w trakcie zniewolenia narodu polskiego, a także po zakończeniu II wojny światowej, zwracając uwagę również na relacje między wychowaniem a polityką oraz na społeczną myśl edukacyjną. Ponadto toruńscy historycy wychowania prowadzą badania biograficzne, koncentrując się na życiu i działalności osób zasłużonych dla polskiej oświaty nauki i kultury w XIX i XX w. Przedmiotem zainteresowań badawczych uczynili również polską myśl pedeutologiczną, w szczególności przypominając zasłużonych nauczycieli dla teorii i praktyki edukacyjnej. Najogólniej można stwierdzić, że w badaniach prowadzonych przez wszystkich wymienionych badaczy toruńskiego ośrodka historii wychowania dominujący jest okres XIX i I połowa XX w. 


\section{Summary}

Celem artykułu jest ukazanie badań naukowych podejmowanych przez toruńskich historyków wychowania - od momentu utworzenia Katedry Pedagogiki w ramach Wydziału Humanistycznego Uniwersytetu Mikołaja Kopernika w Toruniu, aż po współczesne badania prowadzone przez pracowników Katedry Historii Myśli Pedagogicznej na Wydziale Nauk Pedagogicznych UMK. Kierunki prowadzonych badań zależne były od wykształcenia i zainteresowań badawczych uczonych. Należy podkreślić, że badania dotyczyły czasów od dziejów Komisji Edukacji Narodowej aż po XX w., ze szczególnym zwróceniem uwagi na XIX i I poł. XX w. Początkowe publikacje autorów toruńskich z zakresu historii wychowania i myśli pedagogicznej dotyczyły instytucji oświatowych na ziemiach polskich, a także osób zaangażowanych w ich rozwój. Natomiast w kolejnych latach zakres prowadzonych badań uległ rozszerzeniu. Skoncentrowano się na analizie twórców historii myśli pedagogicznej XIX i początków XX w. Podejmowano również badania nad koncepcjami oświatowymi powstałymi w okresie II Rzeczypospolitej, w trakcie II wojny światowej, jak i po jej zakończeniu, uwzględniając relacje między wychowaniem a polityką oraz społeczną myśl edukacyjną. Ponadto toruńscy historycy wychowania prowadzą badania biograficzne oraz analizują polską myśl pedeutologiczną, przypominając nauczycieli zasłużonych dla teorii i praktyki edukacyjnej.

Słow a kluczowe: badania naukowe, twórcy historii wychowania, polska myśl pedeutologiczna, teoria i praktyka pedagogiczna

\section{Summary}

\section{Pedagogical Thought in Scientific Researches of TORUŃ Historians OF EdUCATION}

This article aims to present the scientific researches undertaken by Torun's historians of education from the moment of creation of the Pedagogy Chair in the scope of the Faculty of Humanities of the Nicolaus Copernicus University in Torun until current research conducted by the staff of the Pedagogi- 
cal Thought History Chair at the Faculty of Pedagogy. The directions of the research depended on the education and scientific interests of the researchers. It should be emphasized that the scope included times from the Komisja Edukacji Narodowej (Commission of National Education) until the $20^{\text {th }}$ century, with special attention paid to the $19^{\text {th }}$ century and the first half of the $20^{\text {th }}$ century. The initial publications of the authors in the scope of history of education and pedagogical thought concerned education institutions within Polish territories as well as persons involved in their development. Later the scope of research was expanded. Focus was put on the analysis of output of the creators of pedagogical thought history of the $19^{\text {th }}$ and early $20^{\text {th }}$ centuries. Research was also undertaken on the educational concepts created during the period of $2^{\text {nd }}$ Polish Republic, during World War 2 and after it, considering the relations between education and politics and social educational thought. Moreover the Torun education historians conduct biographical research and analyse Polish pedeutological thought commemorating teachers merited for the educational theory and practice.

Keywords: scientific research, creators of education history, Polish pedeutical thought, pedagogical theory and practice 